\title{
WAGES, FLEXIBLE EXCHANGE RATES, AND MACROECONOMIC POLICY*
}

\author{
JEFFREY SACHS
}

In an open economy with a floating exchange rate, the efficacy of fiscal and monetary policy depends fundamentally on the wage-setting process. In the canonical models of Mundell and Fleming, monetary expansion raises output via an exchange rate depreciation, while fiscal expansion has no output effect. These results hold only when real wages can be altered by exchange rate movements; if the real wage is fixed, the Mundell-Fleming ranking of policy is reversed. This paper explores the interaction of wages and policy in short- and long-run models, under the assumptions of perfect foresight and world capital mobility.

After seven years of floating exchange rates, the implications of flexible rates for countercyclical macroeconomic policy remain in doubt. The traditional view, following the pioneering work of Mundell [1963] and Fleming [1962] (henceforth M-F), is that expansionary monetary policy, by inducing depreciation of the real exchange rate, is effective in raising output in a small, underemployed economy. Fiscal policy, on the other hand, is seen as less effective. In the standard analysis, a rise in government spending leads to appreciation and crowding-out of net exports.

An alternative view of flexible rates, set forth in the full-employment models of global monetarism, maintains that a money supply expansion can change only the exchange rate and price level, but not output and employment. While an increase in money causes depreciation of the nominal exchange rate, the domestic price level rises to offset the competitive gain envisaged in the M-F model. The alternative view has had less to say on the effects of fiscal policy and on the general question of prolonged unemployment.

Both views of monetary policy have adherents, and there is evidence, in different countries and at different times, to support each. Their appropriateness, I shall argue here, depends crucially on the nature of the wage-determination process. The M-F model (in an extended form) requires that nominal exchange-rate changes alter the real wage. ${ }^{1}$ Implicit is an underlying view, going back to Keynes,

* I would like to thank Michael Bruno, Rudiger Dornbusch, Dale Henderson, and Janet Yellen for very helpful discussions, and Susanna French for editorial assistance.

1. The original models ignore wages altogether, letting prices be rigid. Since the econometric evidence overwhelmingly suggests that prices are markups over wages, we adopt the interpretation that wages are rigid and that prices adjust to wages. Prices are later described according to a variable markup, in line with marginal-cost pricing. None of the qualitative conclusions of the paper are changed if we adopt a fixed-markup pricing rule. 
that in the short run, nominal wage changes proceed somewhat independently of price level changes. A contrasting hypothesis is that real-wage developments are little influenced by nominal values. In this case the M-F conclusions regarding monetary and fiscal policy are reversed.

The suggestion that real-wage rigidity vitiates monetary policy is familiar from closed-economy models. However, the mechanism through which wage determination and output are connected is quite different in the closed-and open-economy cases. In the open economy the consumer price level is a function of domestic and foreign prices. The general price level can change even when domestic prices are fixed. Monetary policy has direct links to prices through exchange-rate changes. Also, there is no one-to-one relationship between real wages (nominal wages deflated by the CPI) and aggregate supply, as there is in a closed-economy model. The output supply of domestic firms is determined by the ratio of wages to domestic prices. Since the ratio of domestic to foreign prices can be altered, different levels of aggregate supply are consistent with the same real wage. Finally, a real wage decline increases output through different channels in closed-and open-economy models. In the closed economy a drop in real wages tends to reduce the real interest rate, thus boosting aggregate demand. In the open economy, which faces a given world real interest rate, the path is from real wages to international price competitiveness.

The analysis is divided into three parts. In Section I some data are presented to support the relevance of models with short-run real-wage rigidity. In Section II the short-run M-F model is extended to compare the implications of nominal-wage and real-wage rigidity. The simple comparative statics results repeat the conclusions in Casas [1975], Argy and Salop [1977], and Sachs [1978]. New results are obtained by allowing for short lags in wage indexation and changes in real-wage levels over time. The time horizon of the short-run model is extended in Section III, where we allow for wealth effects due to current account imbalances.

\section{WAGE DETERMINATION IN OECD ECONOMIES}

Two contrasting views of wage determination have dominated macroeconomic discussions in recent years, labeled by Perry [1975] as wage-inertia (or wage-wage) versus wage-price models. In the first, wages follow an auto-regressive scheme; nominal-wage change in the current period is determined by the past pattern of nominal-wage change and by the level of unemployment. In the wage-price model 
nominal wages adjust to current or expected price changes in order to keep real wages moving close to targets, which may in turn be influenced by the unemployment rate. In the wage-wage model real wages can be altered by anticipated monetary policy, while in the wage-price model they cannot.

The wage-wage hypothesis goes back to Keynes's observation that workers' concern for relative wages may lead to sluggish nominal-wage change in decentralized labor markets. Posner recently offered a dynamic version of this view:

The inflationary process is not, therefore, seen as a question of money wages pursuing profits, or pursuing (with a lag) the course of prices, or pursuing an expected rate of increase in real incomes. It is a leapfrogging process in which each union negotiating officer strives to do at least as well and preferably just a wee bit better than the other members of his club [Posner, 1978, p. 11].

The hypothesis is formalized in a model of overlapping long-term contracts by Taylor [1978].

A number of other studies have concluded that, on the contrary, wage bargains are designed to preserve the trend growth of real wages (see Solow [1979]). Implicit-contract theory predicts that a stable real wage for the duration of a contract may be the market equilibrium of the supply and demand for labor under uncertainty. From another point of view, Hicks predicts that stable real-wage growth will result from labor-supply behavior and the activity of trade unions. He describes why workers will resist real wage declines:

The wage-earner's test for fair wages is not simply a matter of comparison with other peoples' earnings; it is also a matter of comparison with his own experience, his own experience in the past. It is this which makes him resist a reduction in his money wage, but it also makes him resist a reduction in the purchasing power of his wages, and even a reduction in the growth of that purchasing power to which he has become accustomed [Hicks, 1975, p. 5].

With sufficient market power, Hicks continues, the worker's trade union will be successful in protecting real wage growth in the short run. Solow [1979] also describes a formal model of trade-union wage behavior for which real-wage stickiness is a likely outcome.

Descriptive studies of labor-market institutions as well as econometric analysis suggest that the real-wage model is for many countries more relevant for short-run microeconomic models (though the United States is a case where significant wage inertia is apparent). Formal indexation of wages to changes in the consumer price index is common throughout the world. ${ }^{2}$ The scala mobile of Italy guar[1976].

2. For a survey of indexation arrangements in industrial countries, see Braun 
TABLE I

Annual Percentage Change in Real Hourly Compensation: 1960-1977

\begin{tabular}{cccccccc}
\hline \hline & $\begin{array}{c}\text { United } \\
\text { States }\end{array}$ & $\begin{array}{c}\text { United } \\
\text { Kingdom }\end{array}$ & France & Germany & Italy & Canada & Japan \\
\hline $1960-73$ & 1.86 & 3.41 & 5.12 & 6.66 & 7.50 & 2.86 & 8.33 \\
$1973-75$ & 0.40 & 6.36 & 5.56 & 7.15 & 8.10 & 3.80 & 4.76 \\
$1973-76$ & 1.14 & 4.68 & 5.56 & 5.21 & 5.82 & 4.15 & 2.99 \\
$1973-77$ & 1.40 & 2.15 & 4.87 & 5.19 & 5.56 & 3.59 & 2.60 \\
\hline \hline
\end{tabular}

Source. Real hourly earnings are calculated as average hourly compensation in manufacturing deflated by the consumer price index. The wage data are from the U. S. Department of Labor, Bureau of Labor Statistics, Office of Productivity and Technology, Output per Hour. Hourly Compensation, and Unit Labor Costs in Manufacturing, Eleven Countries, 1950-1977 (May 4, 1978); the price data are from the International Financial Statistics of the IMF.

antees close to 100 percent indexation of wages for a large segment of the work force (see Lubitz [1977] and Faustini [1976]). Incomes policies in Britain have actively encouraged the use of contracts that link wages to the consumer price index (see Miller [1976], p. 513). Similarly, it has been shown that the Australian Conciliation and Arbitration Commission sets the National Minimum Award Wage to protect (or indeed to accelerate) real-wage growth (see Pitchford [1977]). Further examples abound.

These mechanisms for preserving real-wage growth have been tested in recent years. Table I illustrates the constancy of real wage growth in the face of the worldwide "great recession" of the mid1970 's. In Bruno and Sachs [1979b] it is argued that the 1973 oil-price hike and the boom in primary commodities required a substantial deceleration of real-wage change for output growth to be maintained. Except in the United States and Japan, no deceleration in real-wage change is evident until two years into the recession; in 1976 real wages declined relative to trend. The very high inflation rates in 1973 and 1974 did little to moderate real wages.

Elsewhere [Bruno and Sachs, 1979b] I describe a test to discriminate between wage-wage and wage-price behavior in seven OECD economies. Regressions are presented describing nominal-wage change as a linear function of past wage changes, expected price changes, and lagged unemployment. In France, Germany, Italy, Japan, and the United Kingdom, the coefficient on lagged wages is not significantly different from zero when expected inflation is included in the regression; only in Canada and the United States did lagged wage change affect current wage change. Only in the latter two countries is there evidence that changes in expected inflation alter 
the real wage, as is required in the M-F model. ${ }^{3}$ As is suggested by Table I, real wages exhibited a statistically significant lagged response to unemployment in all countries except the United States and Canada.

\section{THE SHORT-RUN MODEL}

In this section it is shown that real-wage rigidity alters the ranking of monetary fiscal policy in the short-run M-F model, as first described in Casas [1975]. The comparative statics results of the real-wage model are extended to include two dynamic elements: lags in wage indexation: and declines in real wages in response to sustained unemployment.

The following notation is used:

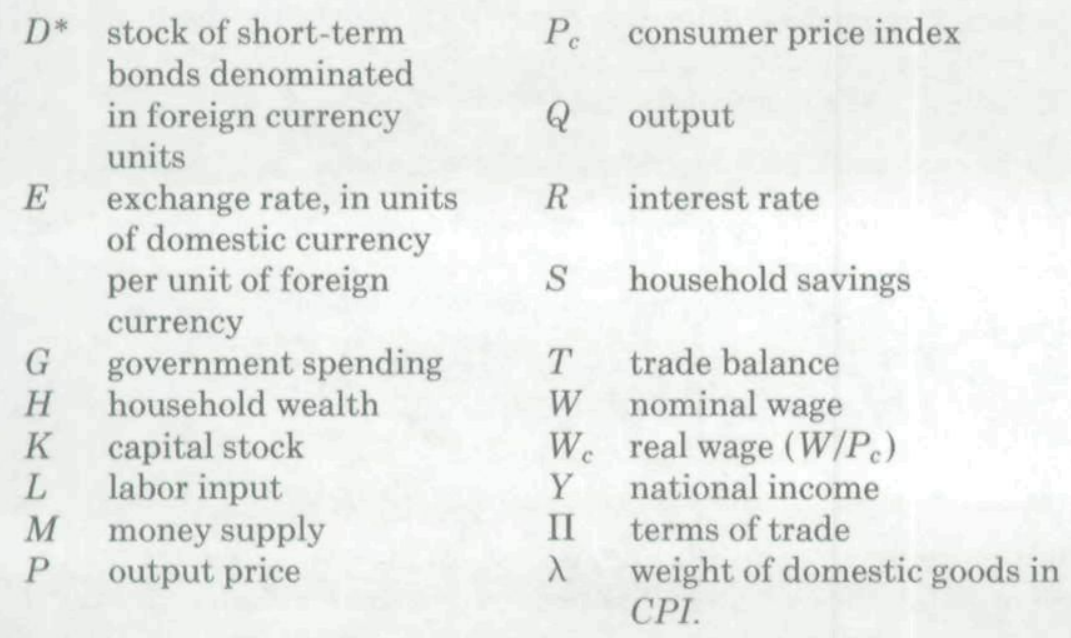

Superscript $e$ indicates expectation; asterisk indicates foreign; lower-case letters denote logarithms of upper-case variables. For all $X, X_{i}$ denotes the partial derivative of $X$ with respect to its $i$ th arguments. The time rate of change of $X, d X / d t$, is denoted by $\dot{X}$, the steady-state value of $X$ by $\bar{X}$.

We turn first to the aggregate supply side. Technology is characterized by the neoclassical production function $F(K, L)$ with fixed

3. Using the notation listed below, the estimated equation is $\dot{w}_{t}=\alpha_{0}+\alpha_{1}(\log$ manhours) $+\alpha_{2} \dot{w}_{t-1}+\left(1-\alpha_{2}\right) \dot{p}_{c t}^{e}+\alpha_{3}$ (time) $+\epsilon_{t}$. If $\alpha_{2}=1$, we have a pure wage-wage process. If $\alpha_{2}=0$, we have a wage-price process. The regression can be rearranged to yield $\dot{w}_{c}=\alpha_{0}+\alpha_{1}(\log$ manhours $)-\alpha_{2}\left(\dot{p}_{c t}^{e}-\dot{w}_{t-1}\right)+\left(\dot{p}_{c t}^{e}-\dot{p}_{c t}\right)+\alpha_{3}($ time $)+\epsilon_{t}$. If $\alpha_{2}>0$, an acceleration of expected inflation above last period's nominal-wage change will reduce the real wage. For details see Bruno and Sachs [1979b]. 
capital stock. Firms operate under conditions of perfect competition, and employ labor according to $W / P=F_{2}$. Simple duality theory permits us to write output as $Q=Q(W / P, K)$ and $Q_{1}<0$ and $Q_{2}>0$. Log-linearizing, and ignoring the constant capital stock, we have ${ }^{4}$

$$
q=-\alpha(w-p) \quad \text { output supply. }
$$

With domestic consumption of home and foreign goods, a true price index may be approximated by $P_{c}=P^{\lambda}\left(P^{*} E\right)^{(1-\lambda)}$, where $\lambda$ is the share of domestic goods in domestic consumption (the index is exact for a Cobb-Douglas utility function). Thus, $p_{c}=\lambda p+$ $(1-\lambda)\left(p^{*}+e\right)$. Equation (1) may be rewritten as

$$
q=-\alpha w_{c}+\beta \pi,
$$

where $\pi=p-p^{*}-e, w_{c}=w-p_{c}$, and $\beta=(1-\lambda) \alpha$. For any given real wage, an increase in the terms of trade $\pi$ reduces the product wage $(w-p)$, thus raising aggregate supply.

We adopt a simple form for the two wage hypotheses:

$$
w=w_{0}+\theta p_{c} \quad \text { wage equation. }
$$

For $\theta=0$, nominal wages are fixed at $w_{0}$. For $\theta=1$, real wages are fixed at $w_{0}$.

A semi-reduced-form aggregate demand schedule is specified: ${ }^{5}$

$$
q=\gamma_{1} D^{*}+\gamma_{2} g+\gamma_{3} T \text { aggregate demand }
$$

and

$$
T=-\theta_{1} q+\theta_{2} q^{*}-\theta_{3} \pi \text { trade balance. }
$$

In (3) aggregate demand is a positive function of net claims on foreigners, $D^{*}$, through a wealth effect, ${ }^{6}$ a positive function of the fiscal

4. For a CES production technology, $\alpha=a \sigma /(1-a)$, where $\sigma$ is the elasticity of substitution and $a$ is the output elasticity with respect to labor.

5. Consider the following brief derivation (see Dornbusch [1976a], for a similar model). With a Metzler savings function, savings is proportional to the gap between desired wealth $H^{d}$ and actual wealth $H$. We define net household wealth as the net bond claims of domestic residents on the rest of the world, in domestic currency units $E D^{*} / P$ (high-powered money is not included in wealth, for reasons described in note 6). In turn, $H^{d}$ is a fixed multiple of disposable labor income. For labor share in output $a$, we have $S=u\left(H^{d}-H\right), H^{d}=\lambda(a Q-G)$ (with a balanced budget and ignoring domestic bonds, taxes equal government spending $G$ ). From the national-income accounting identity, $C+S+$ Tax $=Y$, where $Y$ is national income. In turn, $Y=Q+$ $R^{*}\left(E D^{*} / P\right): Y$ is equal to domestic output plus net income flows from abroad. Finally, $Q=C+G+T$. Putting all the pieces together, we find that $Q=\left[\left(u+R^{*}\right)\left(E D^{*} / P\right)\right.$ $+u \lambda G+T] / u \lambda a$. To get (3), we $(\log )$ linearize around the initial equilibrium $D^{*}=0$ : $E / P=1$. Note that when $T=-R^{*}\left(E D^{*} / P\right)$ (i.e., the current account is balanced), $Q$ is an increasing function of $D^{*}$. This will be important in Section III.

6. High-powered money is a very small fraction of household wealth, and can thus be ignored. By leaving $M / P$ out of $H$, we simplify the analysis by ensuring superneutrality in the real-wage model. The real side of the model may be solved independently of the nominal exchange rate. For a discussion of this assumption see Blanchard [1979]. 
variable $G$, and an increasing function of the net trade balance $T$. In (4) we take the simplified view that export and import demand are functions only of output and the terms of trade. Assuming that Marshall-Lerner conditions are satisfied, we have that $\theta_{3}>0$.

The model is closed by specifying the asset-market structure and the accumulation of domestic wealth,

$$
m-p=\phi q-b R+\delta D^{*} \text { money demand. }
$$

Money demand is an increasing function of domestic output and bond wealth and a decreasing function of the domestic short-term interest rate. ${ }^{7}$ Given perfect capital mobility, the rate of expected depreciation must equal the interest-rate differential,

$$
(\dot{e})^{e}=R-R^{*} \quad \text { covered interest arbitrage. }
$$

Finally, domestic holdings of foreign debt change according to the current-account balance, which is the sum of the trade balance and the debt-service account,

$$
(e / P) \dot{D}^{*}=T+R^{*}\left(e D^{*} / P\right) \quad \text { current-account balance. }
$$

The model is solved in three steps. First, the simplest M-F model is analyzed: a short-run perspective is adopted, and changes in $D^{*}$ according to (7) are ignored. Next, two dynamic elements are added to the real-wage version of the model: lags in wage indexation and longer run responses of real wages to unemployment. Finally, in the next section equation (7) is reintroduced and a more accurate, longrun model is examined.

Solving equations $\left(1^{\prime}\right)-(5)$ and imposing the rational expectation that $(\dot{e})^{e}=\dot{e}=0$, we find that

$$
\begin{aligned}
d q= & \theta d g\left[\alpha \gamma_{2}(1-\lambda) \Delta^{-1}\right]+(1-\theta) d m\left(\alpha \gamma_{3} \theta_{3} \Delta^{-1}\right) \\
& +\theta d q^{*}\left[\gamma_{3} \theta_{2} \alpha(1-\lambda) \Delta^{-1}\right]-d w_{0}\left(\gamma_{3} \theta_{3} \Delta^{-1}\right),
\end{aligned}
$$

where $\Delta=\gamma_{3} \theta_{3}[1+(1-\theta) \alpha \phi]+\theta \alpha(1-\lambda)\left(1+\theta_{1} \gamma_{3}\right)>0$. Fiscal policy is effective for a fixed real wage $(\theta=1)$, and ineffective when the nominal wage is rigid $(\theta=0)$. The reverse is true for monetary policy. The home economy is insulated from changes in foreign output $q^{*}$ only when the nominal wage is rigid; otherwise the shock is transmitted positively. Finally, attempts to raise the real wage by increasing $w_{0}$ reduce income.

Consider these results in terms of aggregate supply $\left(1^{\prime}\right)$. Monetary policy works in the M-F model by reducing real wages; fiscal policy

7. Money demand is written as a function of $E D^{*} / P$ and then linearized about the point $D^{*}=0$. As is well-known, if the initial claims on foreigners are positive, or if the money stock is deflated by $P_{c}$ rather than $P$, the strong M-F result about the inefficacy of fiscal policy disappears. I have chosen the specification in (5) in order to better contrast the cases of nominal and real wages. 
is ineffective because, although it improves the terms of trade, the fiscal expansion raises real wages. Analytically,

$$
d w_{c}=a_{1} d g+a_{2} d q^{*}-a_{3} d m,
$$

where $a_{1}=(1-\theta) \gamma_{2}(1+\alpha \phi)(1-\lambda) \Delta^{-1} \geq 0 ; a_{2}=(1-\theta) \gamma_{3} \theta$ $(1+\alpha \phi)(1-\lambda) \Delta^{-1} \geq 0 ; a_{3}=(1-\theta)\left[\gamma_{3} \theta_{3}+\alpha(1-\lambda)\left(1+\theta_{1} \gamma_{3}\right)\right] \Delta^{-1}$ $\geq 0$. When the real wage is fixed, fiscal policy raises the terms of trade while monetary policy has no effect on $w_{c}$ or $\pi .^{8}$

The effects of $m, g$, and $q^{*}$ on wages are understood by turning to the asset markets. In the short run an increase in $m$ causes a depreciation of the exchange rate, a rise in import prices, and a rise in $p_{c}$. If nominal wages are sticky, the real wage declines. Contrariwise, a fiscal expansion induces an appreciation and reduces $p_{c} \cdot{ }^{9}$ With $\theta=0, w_{c}$ rises.

The assumption of a fixed short-run real-wage can be made more realistic in two important ways. First, even when labor-market institutions are geared to preserve a given short-run real wage, $w_{c}$ might vary because of lags in indexation of wages to price movements (see Modigliani [1978] for such a view). Second, the real wage will eventually respond to unemployment. We now turn to these modifications.

8. The equation for $d \pi$ is

$$
\begin{aligned}
d \pi= & d g\left(\gamma_{2}[1+(1-\theta) \alpha \phi] \Delta^{-1}\right)-d m(1-\theta)\left[\alpha\left(1+\theta_{1} \gamma_{3}\right) \Delta^{-1}\right] \\
& +d q^{*}\left(\gamma_{3} \theta_{2}[1+(1-\theta) \alpha \phi] \Delta^{-1}\right)+d w_{0}\left[\left(1+\theta_{1} \gamma_{3}\right) \alpha \Delta^{-1}\right] .
\end{aligned}
$$

9. An increase in the money supply exerts downward pressure on interest rates. At a given world interest rate, an incipient capital outflow is induced, leading to currency depreciation. The fiscal expansion puts upward pressure on interest rates, and causes currency appreciation. The equations for $d p_{c}$ and $d e$ are

$$
d p_{c}=-b_{1} d g-b_{2} d q^{*}+b_{3} d m-b_{4} d w_{0}
$$

where

$$
\begin{aligned}
& b_{1}=\gamma_{2}(1+\alpha \phi)(1-\lambda) \Delta^{-1}>0 ; \\
& b_{2}=\gamma_{3} \theta_{2}(1+\alpha \phi)(1-\lambda) \Delta^{-1}>0 ; \\
& b_{3}=\left[\gamma_{3} \theta_{3}+\alpha(1-\lambda)\left(1+\theta_{1} \gamma_{3}\right)\right] \Delta^{-1}>0 ; \\
& b_{4}=\left[\phi \gamma_{3} \theta_{3} \alpha-(1-\lambda)\left(1+\theta_{1} \gamma_{3}\right) \alpha\right] \Delta^{-1} \gtrless 0 ; \\
& d e=-c_{1} d g-c_{2} d q^{*}+c_{3} d m+c_{4} d w_{0},
\end{aligned}
$$

where

$$
\begin{aligned}
& c_{1}=\gamma_{2}[1+(1-\theta \lambda) \alpha \phi] \Delta^{-1}>0 ; \\
& c_{2}=\gamma_{3} \theta_{2}[1+(1-\theta \lambda) \alpha \phi] \Delta^{-1}>0 ; \\
& c_{3}=\left[\gamma_{3} \theta_{3}+\alpha\left(1+\theta_{1} \gamma_{3}\right)(1-\theta \lambda)\right] \Delta^{-1}>0 ; \\
& c_{4}=\left[\phi \gamma_{3} \theta_{3} \alpha-\left(1+\theta_{1} \gamma_{3}\right) \alpha\right] \Delta^{-1} \gtrless 0 .
\end{aligned}
$$




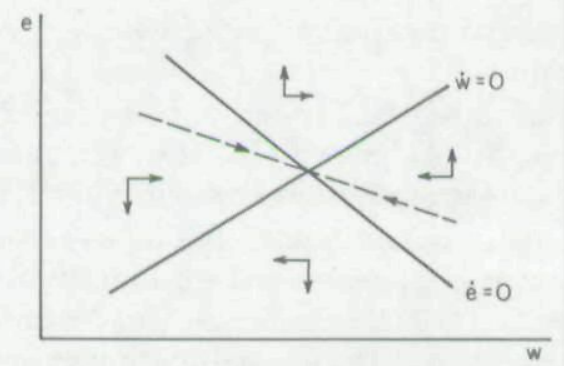

1a. Case of $1+\gamma_{3} \theta_{1}-\phi \gamma_{3} \theta_{3}>0$

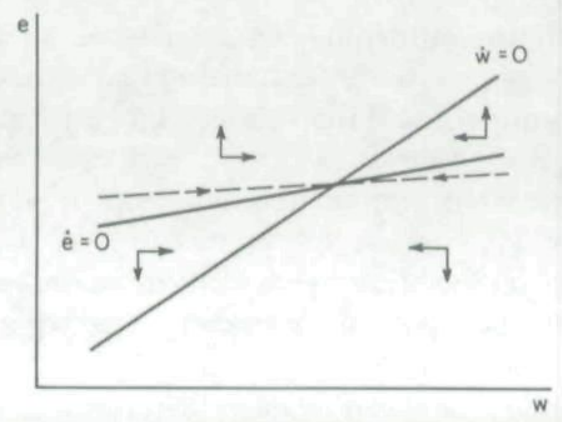

1b. Case of $1+y_{3} \theta_{1}-\phi \gamma_{3} \theta_{3}<0$

Figure I

Wage and Exchange Rate Dynamics

Indexed contracts typically provide for a lag of at least onequarter in wage adjustment following a CPI increase. As an example, in Stage 3 of the British 1972-1974 incomes policy, wage indexation was subject to the condition that nominal wages were not to be adjusted until a threshold price increase had been passed. The effect of the oil price increase in 1973-1974 was to reduce British real wages for two quarters, after which they more than recovered. With informal wage indexation a union may have to wait until the next round of collective bargaining to restore real wages.

These lags suggest a simple dynamic rendering of the real-wage model. Instead of (2) we write

$$
\begin{aligned}
& w^{t}=w_{0}+p_{c} \\
& \dot{w}=\psi\left(w^{t}-w\right),
\end{aligned}
$$


where $w^{t}$ is the target nominal wage. Actual wages adjust to close the gap between $w$ and $w^{t}$.

A number of interesting conclusions emerge from the solution of $\left(1^{\prime}\right),\left(2^{\prime}\right)$, and (3)-(6). Because of the lags in wage adjustment, monetary policy will work in the short run, even though the equilibrium real wage is fixed. On impact, the money expansion increases $q$; later, domestic price increases cause $q$ to return to the initial level. Fiscal multipliers, on the other hand, are smaller in the short run than in the steady state. Indeed: the impact multipliers of a fiscal expansion may be negative. Finally, exchange rates may overshoot or undershoot long-run values after a policy change, for reasons described in Dornbusch [1976b].

Once again, the multiplier results are best understood in terms of aggregate supply. A money expansion causes a spot depreciation, reducing $w_{c}$ on impact and increasing aggregate supply at the given terms of trade. Since aggregate supply exceeds aggregate demand, the terms of trade worsen, competitiveness improves, and domestic demand increases. Aggregate supply contracts as $w_{c}$ rises toward $w_{0}$. The fiscal expansion, on the other hand, induces an appreciation and raises $w_{c}$. As $w$ falls in response to the reduced $p_{c}$, aggregate supply expands to the level shown in (8).

The dynamic model can be described formally by a two-variable linear differential equation system:

$$
\left[\begin{array}{l}
\dot{w} \\
\dot{e}
\end{array}\right]=\left[\begin{array}{ll}
a_{11} & a_{12} \\
a_{21} & a_{22}
\end{array}\right]\left[\begin{array}{c}
w-\bar{w} \\
e-\bar{e}
\end{array}\right],
$$

where

$$
\begin{aligned}
& a_{11}=-\psi \Delta_{1}^{-1}\left[\theta_{3} \gamma_{3}+(1-\lambda) \alpha\left(1+\gamma_{3} \theta_{1}\right)\right]<0 ; \\
& a_{12}=-a_{11}>0 ; \\
& a_{21}=b^{-1} \Delta^{-1}\left[\alpha\left(1+\gamma_{3} \theta_{1}-\phi \gamma_{3} \theta_{3}\right)\right] \gtrless 0 ; \\
& a_{22}=b^{-1} \Delta^{-1}\left(\theta_{3} \gamma_{3}+\phi \alpha \theta_{3} \gamma_{3}\right)>0 ;
\end{aligned}
$$

and

$$
\Delta_{1}=\alpha\left(1+\gamma_{3} \theta_{1}\right)+\theta_{3} \gamma_{3} .
$$

Because the determinant $a_{12} a_{22}-a_{21} a_{12}<0$, the characteristic roots are real and of opposite sign, indicating saddlepoint stability. The phase plane representation is shown in Figure I, for the two cases $1+\gamma_{3} \theta_{1}-\phi \gamma_{3} \theta_{3}>0$ and $1+\gamma_{3} \theta_{1}-\phi \gamma_{3} \theta_{3}<0$. The dashed line indicates the single stable arm; the exchange rate always jumps to keep the economy along the stable trajectory. 


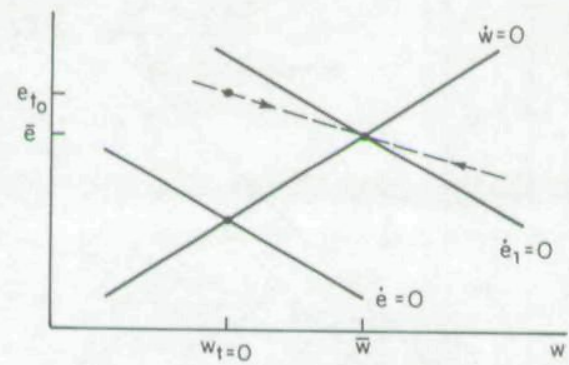

2a. Monetary expansion: case of $1+y_{3} \theta_{1}-\phi y_{3} \theta_{3}>0$

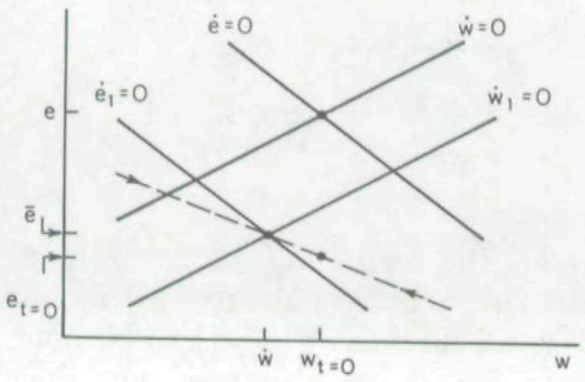

2b. Fiscal expansion: case of $1+y_{3} \theta_{1}-\phi y_{3} \theta_{3}>0$

Figure II

Monetary and Fiscal Expansion

Consider a monetary and fiscal expansion in the case $1+\gamma_{3} \theta_{1}$ $-\phi \gamma_{3} \theta_{3}>0$. After a money supply increase (Figure IIa), the exchange rate depreciates to $e_{t=0}$. The price level rises, and $w_{c}$ falls. Subsequently, wages and prices rise to the new equilibrium, in equiproportion to the money supply increase. The fiscal expansion (Figure $\mathrm{IIb}$ ) induces a spot appreciation and reduces prices. Since $w_{c}$ rises, the impact multiplier is less than the multiplier calculated earlier.

In the case of $1+\gamma_{3} \theta_{1}-\phi \gamma_{3} \theta_{3}<0$, the impact fiscal multiplier is negative (Figure III). The spot appreciation of the exchange rate is less than the long-run appreciation. Since $\dot{e}<0$ at $t_{0}$, we must have $R<R^{*}$. Given money-market equilibrium, this is possible only if at $t_{0}, q$ falls below its initial level.

Finally, it is easy to show that a monetary expansion will cause the exchange rate to overshoot if and only if $1+\gamma_{3} \theta_{1}-\phi \gamma_{3} \theta_{3}>0$ (the graphical proof is immediate). 


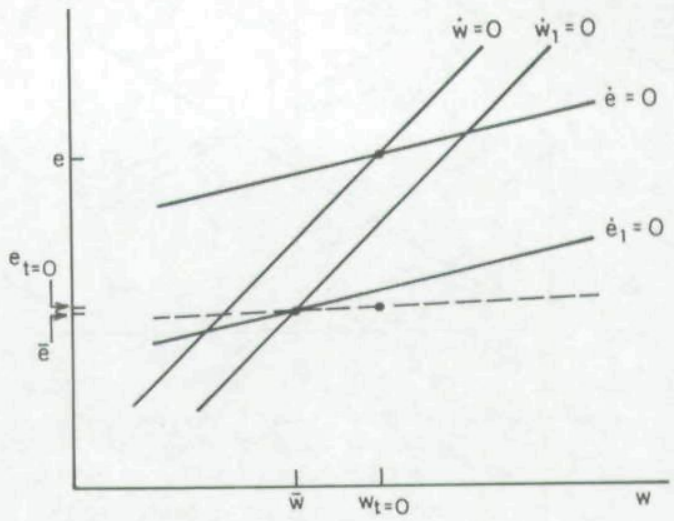

Case of $1+\gamma_{3} \theta_{1}-\phi \gamma_{3} \theta_{3}<0$

Figure III

Fiscal Expansion

Our analysis of the simple M-F model is completed by treating the case of short-run real-wage rigidity with longer-run real-wage flexibility. In Bruno and Sachs [1979a] an economy is described in which real wages respond slowly to the gap between the labor input and long-run desired labor supply. After an expansionary shock in $g$ or $q^{*}$, output rises according to (8). Labor input also rises, by the amount $d q / a$, where $a$ is the output elasticity of labor. If desired labor supply is not infinitely elastic, there will be excess demand for labor at the initial $w_{c}$, and real wages will begin to rise. We saw earlier that increases in $w_{0}$ reduce output, so the induced rise in real wages reduces the multipliers of $g$ and $q^{*}$ on $q$. Some of the expansionary effect is dissipated by an increase in $w_{c}$ and $\pi$, and a fall in world competitiveness. ${ }^{10}$

\section{THE LONG-RUN MODEL}

As is well-known, the short-run M-F model is seriously flawed by its failure to treat the long-term wealth effects of current-account

10. Suppose that the long-run wage elasticity of labor supply is $\rho$, and that the real wages adjust slowly to close the gap between labor input and desired supply: $\dot{w}_{c}$ $=\mu\left(l-l^{s}\right)=\mu\left(l-\rho w_{c}\right)$. Since $l=q / a$ (up to a constant term), equilibrium real wages are given by $w_{c}=q / \rho a$. If we add this condition to the model solved earlier (in the case of $\theta=1$ ), the output equation is $d q=d g\left[\alpha \gamma_{2}(1-\lambda) \Delta_{2}^{-1}\right]+d q^{*}\left[\gamma_{3} \theta_{2} \alpha(1-\lambda) \Delta_{2}^{-1}\right]$, where $\Delta_{2}=\gamma_{3} \theta_{3}(1+\alpha / \rho a)+(1-\lambda)\left(1+\theta_{1} \gamma_{3}\right)>\Delta>0$. The multipliers on $g$ and $q^{*}$ have been reduced. 
imbalance. ${ }^{11}$ Here we add the wealth effects to the model of Section I, to see whether the distinction between nominal-wage and real-wage rigidity remains important in the long run. The answer is that it does, though in an unexpected way.

As shown in Rodriguez [1979] and Sachs [1979], the conclusions of the M-F model must be altered if the wealth flows due to currentaccount imbalances are taken into account. With a fixed nomimal wage the long-run multipliers of monetary and fiscal policy are both likely to be positive, unlike the zero multiplier on $g$ in the model of Section I. With real-wage rigidity, the money multiplier is again zero, given the nominal-real dichotomy of the long-run model. The long-run fiscal multiplier, however, is negative.

Under both wage assumptions, the fiscal expansion raises output and leads to a current-account deficit on impact. $D^{*}$ falls according to (9). The decline in wealth causes aggregate demand to fall. If real wages are rigid, the initial output level is reached and the trade account is again in balance. But the decline in $D^{*}$ has now moved the debt-service account into deficit, and the overall current account remains in deficit. Output must decline still further in order to reduce imports, thus balancing the debt-service account deficit with a trade-account surplus. With fixed nominal wages, the decline in $D^{*}$ is eventually accompanied by a depreciation of the currency. Real wages fall, aggregate supply expands, and the economy's international competitiveness improves. The current account is balanced at a higher level of output because of the improvement in competitiveness.

The long-run multipliers are found by solving equations $\left(1^{\prime}\right)$, (2)-(6), and requiring that $\dot{D}^{*}=0$ in (7). Equation (7) is linearized around $E / p=1, \Delta^{*}=T=0$, so that $\dot{D}=T+R^{*} D^{*}$ :

where

$$
\begin{aligned}
d q= & {\left[\Delta_{3}{ }^{-1}\left(\gamma_{1}-\gamma_{3} R^{*}\right)(1-\theta) \theta_{3} \alpha\right] d m } \\
& +\left[\delta \theta_{3}(1-\theta) \alpha-R^{*} \alpha(1-\lambda) \theta\right] \gamma_{2} \Delta_{3}{ }^{-1} d g \\
& +\left[\Delta_{3}{ }^{-1} \theta_{2}\left(\gamma_{1}-\gamma_{3} R^{*}\right) \alpha \theta(1-\lambda)\right] d q^{*},
\end{aligned}
$$

$$
\begin{aligned}
\Delta_{3}= & (1-\theta)\left[\phi \theta_{3}\left(\gamma_{1}-\gamma_{3} R^{*}\right) \alpha+\theta_{3} \delta \alpha\right] \\
& +\left(\gamma_{1}-\gamma_{3} R^{*}\right)\left[\theta_{3}+\theta_{1} \alpha \theta(1-\lambda)\right]-\alpha \theta(1-\lambda) R^{*} .
\end{aligned}
$$

$\gamma_{1}-\gamma_{3} R^{*}$ is assumed to be positive. ${ }^{12}$ When $\theta=0, \Delta_{3}$ is necessarily

11. Recent papers that discuss long-run wealth effects of the current account include Dornbusch and Fischer [1978], Rodriguez [1979], and Sachs [1979]. None of these papers compares adjustment under alternative wage assumptions.

12. Since $q=\gamma_{1} D^{*}+\gamma_{2} g+\gamma_{3} T$, and $T=-R^{*} D^{*},\left(\gamma_{1}-\gamma_{3} R^{*}\right)>0$ is the condition that an increase in long-run $D^{*}$ raise aggregate demand. The condition emerges naturally from a structural derivation of equation (3). See note 5 . 
positive. For $\theta=1$, stability requires $\Delta_{3}$ to be positive, and this is assumed. ${ }^{13}$ Thus, for $\theta=0, d q / d m>0$, and $d q / d g>0$. For $\theta=1, d q / d m$ $=0$, and $d q / d g<0$.

These results are sensitive to the specification of the trade balance. We have assumed that net exports depend only on output and not on the distribution of income between the private and public sector. ${ }^{14}$ If a balanced-budget fiscal expansion shifts demand from foreign to home goods, the fiscal policy can increase $q$ in the long run even with rigid real wages. Thus, we must distinguish analytically between the expenditure-increasing and the expenditure-switching effects of government spending. When fiscal policy is effective in the long run, the short-run multiplier will tend to be greater than the long-run multiplier.

The impact effect of fiscal policy is positive in both the nominal-wage and real-wage models. The dynamic equations for the nominal-wage model are

$$
\left[\begin{array}{c}
\dot{e} \\
\dot{D^{*}}
\end{array}\right]=\left[\begin{array}{cc}
b_{11} & b_{12} \\
b_{21} & b_{22}
\end{array}\right]\left[\begin{array}{c}
e-\bar{e} \\
D^{*}-\bar{D}^{*}
\end{array}\right],
$$

where

$$
\begin{aligned}
& b_{11}=b_{1}^{-1} \Delta_{4}^{-1}(\alpha \phi+1) \theta_{3} \gamma_{3}>0 ; \\
& b_{12}=b_{1}^{-1} \Delta_{4}^{-1}\left[\Delta_{4} \delta+\gamma_{1}(\alpha \phi+1)\right]>0 ; \\
& b_{21}=\Delta_{4}^{-1}\left(\theta_{3} \gamma_{3}\left(\alpha \theta_{1}+\theta_{3}\right)+\theta_{3} \Delta_{4}\right)>0 ; \\
& b_{22}=\Delta_{4}^{-1}\left[R^{*} \Delta_{4}-\gamma_{1}\left(\alpha \theta_{1}+\theta_{3}\right)\right] \gtrless 0,
\end{aligned}
$$

where $\Delta_{4}=\alpha+\alpha \gamma_{3} \theta_{1}+\gamma_{3} \theta_{3}>0$.

In Figure IV a phase plane representation of a fiscal expansion is shown for the case $b_{22}<0$. Since $b_{11} b_{22}-b_{21} b_{12}<0$, we again have saddlepoint stability. With a fiscal expansion the $\dot{D}=0$ locus shifts up, and the $\dot{e}=0$ locus shifts down. The exchange rate depreciates along the adjustment path, so $R_{t=0}>R_{t=0}^{*}$. By the money market equation, $y_{t=0}$ must be greater than the pre-expansion level. ${ }^{15}$ Note that the exchange-rate depreciation coincides with a current-account

13. Using (1') and (2)-(7) under the condition $\theta=1$, we find that $d \dot{D}^{*} / d D^{*}=$ $-\Delta_{3}\left[\alpha(1-\lambda)+\alpha(1-\lambda) \gamma_{3} \theta_{1}+\theta_{3} \gamma_{3}\right]^{-1}$. Since this expression must be negative for stability, $\Delta_{3}$ must be positive.

14. Equation (7) suggests that the private and public sector marginal propensities to import are equal, or that imports are in large part intermediate and capital goods, tied less to income than to output.

15. Substituting (1) into (5), $m-w=(\phi+1 / \alpha) q-b R \delta D^{*}$. A rise in $R$ at constant $D^{*}$ requires a rise in $y$ for money-market balance. 


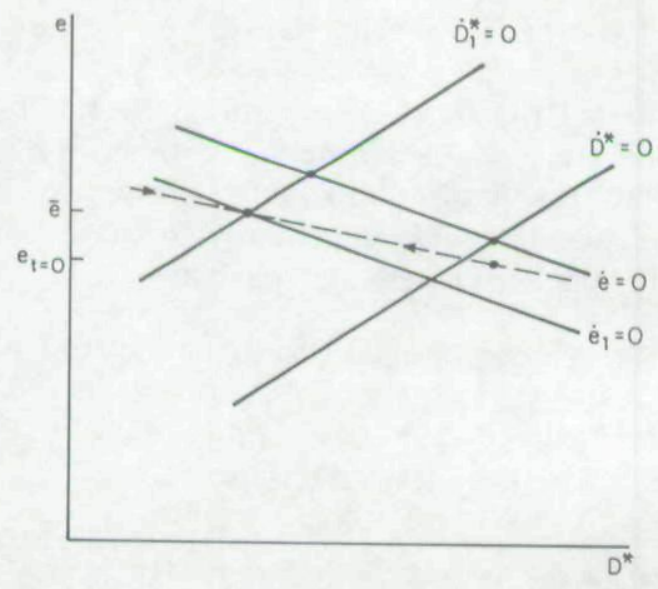

FIGURE IV

Fiscal Expansion in the Long-Run Model with Nominal-Wage Rigidity $\left(b_{22}<0\right)$

deficit, as found in other models (e.g., Dornbusch and Fischer [1978]). In the case, $b_{22}>0$ (not shown), the same conclusions hold.

In the real-wage case, the impact effect of fiscal policy is given by (8), if we ignore lags in short-run indexation. The comparative statics result of the short-run model coincides with the impact effect in the long-run model. As $D^{*}$ falls, $q$ falls below this initial level. By solving the full dynamic system, it may be shown that the exchange rate again depreciates with a current-account deficit and appreciates with a surplus.

\section{CONCLUSIONS}

In discussing the merits of alternative macroeconomic policies for open economies, too little attention has been paid to labor-market analysis. I have argued that the wage-wage and wage-price models lead to fundamentally different conclusions regarding the efficacy of fiscal and monetary policy. At issue is whether real exchange rates and real wages can be changed by movements in nominal exchange rates. If so, the Mundell-Fleming conclusions are upheld; if not, the opposite conclusions obtain.

The distinction between real-wage and nominal-wage adjustment patterns is not merely a feature of small-country models. In the standard short-run, two-country model, a fiscal expansion in one country raises income in both. Not so with fixed real wages in both countries. The fiscal expansion is beggar-my-neighbor, raising income 
at home and decreasing income abroad (see Bruno and Sachs [1979b]).

Unfortunately, the empirical evidence of Section I suggests that the task of policy is complicated by the presence of different wageadjustment patterns in different countries. The two views of wagedetermination must be subjected to more rigorous empirical analysis, so that informed policy choices may be made.

\section{HARVARD UNIVERSITY AND NATIONAL BUREAU OF ECONOMIC RESEARCH}

\section{REFERENCES}

Argy, Victor, and Joanne Salop, "Price and Output Effects of Monetary and Fiscal Policy Under Flexible Exchange Rates," unpublished IMF 9/7/77, 1977.

Blanchard, Olivier Jean, "The Monetary Mechanism in the Light of Rational Expectations," Harvard Institute of Economic Research Discussion Paper No. 682, 1979.

Braun, Anne R., "Indexation of Wages in Developed Economies," IMF Staff Papers, XXIII (No. 1, March 1976).

Bruno, Michael, and Jeffrey Sachs, "Macro-Economic Adjustment with Import Price Shocks: Real and Monetary Aspects," Discussion Paper No. 793, Jerusalem: Falk Institute, 1979a.

_ , and - "Supply Versus Demand Approaches to the Problem of Stagflation," Discussion Paper No. 796, Jerusalem: Falk Institute, 1979b.

Casas, F. R., "Efficient Macroeconomic Stabilization Policies Under Floating Exchange Rates," International Economic Review, XVI (Oct. 1975), 682-98.

Dornbusch, Rudiger, "Capital Mobility, Flexible Exchange Rates and Macroeconomic Equilibrium," in Recent Issues in International Monetary Economics, E. Classen and P. Salin, eds. (Amsterdam: North-Holland, 1976a).

, "Expectations and Exchange Rate Dynamics," Journal of Political Economy, LXXXI (Dec. 1976b), 1161-76.

_ _ and Stanley Fischer, "Exchange Rates and the Current Account," unpublished draft, Cambridge, M.I.T., April 1978.

Faustini, Gino, "Wage Indexation and Inflation in Italy," Banca Nazionale del Lavoro Quarterly Review, No. 119 (Dec. 1976), 364-77.

Fleming, John M., "Domestic Financial Policies under Fixed and under Floating Exchange Rates," IMF Staff Papers, IX (Nov. 1962), 369-79.

Hicks, J. R., "What Is Wrong with Monetarism," Lloyd's Bank Review, No. 118 (Oct. 1975), 1-13.

Lubitz, Ray, "The Italian Economic Crisis of the 1970s," unpublished, Federal Reserve Board, 1977.

Miller, Marcus H., "Can a Rise in Import Prices Be Inflationary and Deflationary? Economists and U. K. Inflation, 1973-74," American Economic Review, LXVI (Sept. 1976), 501-19.

Modigliani, F., and T. Padoa-Schioppa, The Management of an Open Economy with "100\% Plus" Wage Indexation, Essays in International Finance, 130 (Princeton, NJ: Princeton University Department of Economics, 1978).

Mundell, R. A., "Inflation and Real Interest," Journal of Political Economy, LXXI (June 1963), 280-83.

Perry, George L. "Determinants of Wage Inflation around the World," Brookings Papers on Economic Activity, No. 2 (1975), 403-35.

Pitchford, John D., "Inflation in Australia," in Worldwide Inflation, Lawrence B. Krause and Walter S. Salant, eds. (Washington, D. C.: Brookings Institution, 1977), pp. 355-94.

Posner, Michael V., "Problems of the British Economy," in Public Policies in Open Economies, Karl Brunner and Allan H. Meltzer, eds., Carnegie-Rochester Con- 
ference Series on Public Policy, Vol. IX (Amsterdam, New York, Oxford: NorthHolland, 1978), pp. 5-32.

Rodriguez, Carlos Alfredo, "Short- and Long-Run Effects of Monetary and Fiscal Policies under Flexible Exchange Rates and Capital Mobility," American Economic Review, LXIX (March 1979), 176-82.

Sachs, Jeffrey, "Wage Indexation, Flexible Exchange Rates and Macroeconomic Policy," paper presented at the American Economic Association Meetings, Chicago, September 1978.

"Short- and Long-Run Effects of Monetary and Fiscal Policies under Flexible Exchange Rates and Perfect Capital Mobility: Comment," unpublished draft, May 1979.

Solow, Robert M., "Alternative Approaches to Macroeconomic Theory: A Partial View," W. A. Mackintosh Lecture, Queen's University, Kingston, Ontario, March 1979.

Taylor, John B., "Aggregate Dynamics and Staggered Contracts," unpublished, Columbia University, 1978. 
Copyright of Quarterly Journal of Economics is the property of MIT Press. The copyright in an individual article may be maintained by the author in certain cases. Content may not be copied or emailed to multiple sites or posted to a listserv without the copyright holder's express written permission. However, users may print, download, or email articles for individual use. 